Institute of $\mathbf{F}_{\text {ood and }} \mathbf{A}_{\text {gricultural }} \mathbf{S}_{\text {ciences }}$

\title{
Fresh Produce Handling, Sanitation, and Safety Measures: Beans, Cucumbers, Eggplants, Squash, Peppers, Sweetcorn ${ }^{1}$
}

\author{
M. Mahovic, J. Brecht, S. Sargent, M. Ritenour, K. Schneider, A. Simonne, J. Bartz ${ }^{2}$
}

University of Florida Food Quality and Safety Design Team (Michael Mahovic, Jeffrey K. Brecht, Steven A. Sargent, Mark A. Ritenour, Keith R. Schneider, Amy Simonne and Jerry Bartz) for the Fresh Produce Food Safety Southeastern Training Program (CSREES Project No. 00-51110-9722) National Integrated Food Safety Initiative

\section{Introduction}

Maintaining good sanitation throughout handling is important. Human pathogens can be transmitted by direct contact (infected employees or animals) or through contaminated water or soil. Once a vegetable is infested, pathogens are difficult or impossible to remove. Only thorough cooking (or other similar treatment, such as pasteurization) will reliably neutralize pathogens infesting a vegetable.

Vegetables that are field-packed without washing have a higher likelihood of reaching consumers with field contamination. Harvest crews for these commodities must be trained especially well to avoid suspect vegetables or practices. An extra benefit of good sanitation to growers and shippers is that sanitation also reduces infection by plant pathogens and reduces decay during shipping and storage. It is vitally important that growers, and in turn their employees, understand just how critical any food poisoning outbreak could be to their livelihoods.

This document focuses on how to best reduce contamination possibilities to maintain a wholesome product, hopefully thus avoiding any food poisoning outbreaks. These broad areas will be covered:
1.0 Preharvest
2.0 Harvest
3.0 Personnel Cleanliness
4.0 Packing, Storage, and Transport
5.0 Unpacking and Display
6.0 Documentation and Record-Keeping

1. This document is FSHN0213, one of a series of the Food Science and Human Nutrition Department, Florida Cooperative Extension Service, Institute of Food and Agricultural Sciences, University of Florida. Publication: October 2002. Please visit the EDIS Web Site at http://edis.ifas.ufl.edu.

2. M. Mahovic, graduate student; J. Bartz, Ph.D., associate professor, both of Plant Pathology; J. Brecht, Ph.D., professor; S. Sargent, Ph.D., professor; M. Ritenour, Ph.D., assistant professor, all of Horticultural Sciences; K. Schneider, Ph.D., assistant professor, Food Science \& Human Nutrition; A. Simonne, Ph.D., assistant professor, Family Youth and Community Sciences, Cooperative Extension Service, Institute of Food and Agricultural Sciences, University of Florida, Gainesville, FL 32611.

The Institute of Food and Agricultural Sciences is an equal opportunity/affirmative action employer authorized to provide research, educational information and other services only to individuals and institutions that function without regard to race, color, sex, age, handicap, or national origin. For information on obtaining other extension publications, contact your county Cooperative Extension Service office. Florida Cooperative Extension Service/Institute of Food and Agricultural Sciences/University of Florida/Christine Taylor Waddill, Dean. 


\subsection{Preharvest}

\subsection{Irrigation water}

Application method affects water quality requirements. The more water contacts the commodity directly, the more stringently clean the water needs to be.

- If overhead or furrow irrigation is used, water should ideally be tested to be free of coliforms if it may contact the vegetables.

- In a drip irrigation system, emitters under plastic mulch are not likely to transmit pathogens to vegetables so water sanitation is not as critical.

- Pumps and irrigation stations must also be kept free of contaminant sources such as scum build-up, animals, human/animal waste products, etc. If a pump is contaminated, all the water going through the pump and anything that water is sprayed on can become contaminated as well.

Note: Surface water conditions may change from season to season or even day to day, depending on weather, animal or human activities, or other environmental variables. This means it is unreliable in its cleanliness and if used should be used cautiously and tested frequently.

Allow a drying period before harvest. The longer the period between harvest and the last irrigation, the less likely any contaminating pathogens have survived.

\subsection{Frost protection water cleanliness}

Management of frost protection water is similar to that of irrigation if water makes direct vegetable contact. Ideally, water should be of drinking water quality (potable) if it comes in contact with the edible portion of vegetables.

\subsection{Water used for pesticide mixing}

Since pesticide water does come in direct contact with fruit, this water should be from a potable source. Fresh produce has been contaminated by tainted water mixed with pesticides.
In any case where water quality is a concern, numerous factors can affect the microbial load. However, contamination potential can be minimized by following a few general rules:

- Give preference to groundwater sources: they have a lesser chance of becoming contaminated by direct or indirect contact with humans or animals.

- Surface water quality may change from day to day and is subject to animal contamination.

- Municipal water is, of course, potable.

Check with your lab to determine the best local water-testing schedule to keep, as necessary.

\subsection{Animal exclusion}

Most human pathogens are carried by other animals (fowl; reptiles; amphibians; mammals such as dogs, cats, deer, raccoons, etc). Exclusion of as many animals as possible from the field and picking operations will decrease the likelihood of contamination.

- This is a recurring theme from the field and irrigation, to harvest to shipping and storage. Animals can bring contaminants into contact with vegetables at any stage, from farm to fork!

Any animal materials (waste, carcasses, etc.) should be removed immediately from the field if possible (and practical).

- Carcasses should be incinerated or buried.

- Vegetables near these areas should not be harvested.

Workers that come in contact with live animals, animal carcasses or animal waste materials should wash their hands before they continue working.

- This includes any vegetable that may have been the victim of a recent bird fly-by. If a worker touches this vegetable, the material can get on their hands and be spread to any other vegetable they touch. If human pathogens were present in the waste material, all of the vegetables are now potentially contaminated and an outbreak may occur. 


\subsection{Human Hygiene}

If pickers are in the field for more than 3 hours, OSHA requires that there be 1 portable toilet per 20 employees.

- These must be moved with the crews to be kept within $1 / 4$ mile of them at all times.

- They must never be emptied in the field or near surface water sources!

- Appropriate hand-washing facilities are also needed in conjunction with portable toilets.

\section{6 $\underline{\text { Soil Contaminants }}$}

Animal manure applied as fertilizer must be composted unless it is incorporated into the soil not less than 90 days before harvest for crops (such as citrus fruit) that are not in contact with the soil. Fully composted manure should still be handled in such a way that contact between the material and the edible portion of the crop is avoided.

- 'Fully composted' means organic matter has been maintained between $131^{\circ} \mathrm{F}$ and $170^{\circ} \mathrm{F}$ for 3 days using an in-vessel or static aerated pile system, or for 15 days using a windrow composting system, during which period the materials must be turned a minimum of five times (Natl. Organic Prog. Final Rule Sec. 205.203).

Biosolids (human waste) are strictly regulated (Code of Federal Regulations, title 40 part 503).

- They are best to be avoided outright.

- They can NOT be used in organic operations.

Be aware of land use near the grove.

Establishment of citrus groves near animal operations or waste handling facilities should be avoided.

The key is that manures should never have an opportunity to come into contact with vegetables. Vegetables that fall to the ground should only be harvested when the finished product receives a heat kill step such as pasteurization. Drops should never be harvested for fresh market.

\subsection{Harvest and Packing}

\subsection{Pesticide residuals}

Pesticide labels are regulated for safety of product, employees and the environment. It is critical that they be followed.

Remember these points in regard to pesticides, especially re-entry and harvest times:

- Only apply those treatments specifically labeled for the commodity

- Apply pesticides only when and as directed by the label

- Do NOT harvest until the label-designated time

• Always remember: "The Label is the Law!"

\subsection{Animal exclusion}

Animals can easily transmit pathogens. Minimizing animal contact in fields and packing facilities reduces the risk of contamination.

- No domesticated animals should be in the field at harvest.

- No children should be allowed in the grove during harvesting operations.

- Practice animal and insect control in and around harvesting equipment storage areas.

2.3 Culling - The removal of rotten vegetables from the field

Evidence suggests that human pathogens more readily proliferate in injured and decaying produce. This makes it important for vegetables showing bruises or decay symptoms to be culled out as a preventive measure.

- Cull removal is important to avoid spread of decay or harbored human pathogens from contaminated to sound vegetables.

- Simply tossing discards to the bottom of aisles between beds may avoid contamination of that harvest, but leaves a source of inoculum for future contamination. 
Ideally, harvesters should not handle culls in the field. This can spread infection from contaminated to healthy vegetables via the workers hands. Culls should be removed by a separate worker, if possible, so as not to contaminate sound produce.

\subsection{Container cleanliness and sanitation}

Containers used in the field, in packinghouses, and for shipment should all be kept clean until used. If any of the containers are reusable, they should be cleaned regularly with more frequent washings if they become overly soiled. Any disposable containers should be kept clean until use and discarded if they become soiled before use.

- Stored containers can easily become contaminated by rodents, insects, and other animal life. Check stored units for contamination and either replace or clean any that become soiled.

- Store empty containers separately from:

- those already filled with vegetables

- any potential chemical contaminants (e.g. chemical storage areas)

- any other non-sanitary conditions (near waste receptacles, animal infested areas, etc.)

Harvest containers should not be allowed to touch the ground in the field (or in storage), as this may transfer pathogens from the soil to the produce.

Any commodity that grows on or in proximity to the ground should have extra care taken to control soil contaminants, particularly at harvest time.

\subsection{Packinghouse cleanliness}

Animal Exclusion - As in the preharvest and harvest procedures, practice animal and insect control in and around packing facilities.

Cleaning and sanitation of packingline equipment is critical. Just one source of pathogen introduction, at any point, can potentially inoculate all vegetables that pass through the line.
- Cleaning - physically removing debris, biofilm build-up, and any other residuals on the line. This is done with detergent and physical labor (such as scrubbing or a pressure washer, etc.).

- Sanitation - using sanitizers of various types to kill microbes on clean surfaces. Sanitation is most effective after a surface has been cleaned. This is true of packing lines, hands, bins and anything else that may become soiled.

- Many steps can easily be overlooked during cleaning. Here are some key points to remember:

- Remove debris accumulation from all surfaces.

- Clean all surfaces that produce or employees may contact, including bench/table tops, drains, walls, cooler coils, ceilings, etc., as appropriate.

- Clean using a Top-to-Bottom method to avoid re-soiling already cleaned surfaces.

- Closed-in spaces can be fumigated for sanitation.

- Never put vegetables that have fallen from the line back into circulation.

- Have waste receptacles available for employee use and regularly empty and clean them.

- Properly store all equipment after the workday ends.

Regular cleaning greatly reduces opportunities for pathogen build-up and inoculation to occur.

\subsection{Dump tanks and hydrocoolers:}

If using a dump tank or hydrocooling system, sanitizers (e.g. chlorine) used to reduce vegetable pathogens may help control human pathogens as well.

- Wherever possible, drain and clean tanks daily.

- Be sure to rinse out any cleaning solutions before re-filling the tank (e.g. residuals from quaternary ammonium solutions may produce toxic fumes when contacted by chlorinated 
water). Such cleaning solutions are often not registered for direct vegetable contact and may cause injury.

- Be sure to follow the label on all chemical products.

- Vegetables should not be allowed to sit in water for extended periods of time, such as during employee breaks.

\subsection{Personnel Cleanliness}

\subsection{Recognizing symptoms of food-borne human} diseases

It is important to recognize symptoms of illness to better keep sick workers away from the commodity. Some symptoms may include: fever, diarrhea, vomiting, sore throat or jaundice (yellow skin and eyes).

\subsection{Exclusion of ill workers}

Employees that display symptoms of illness should either have appropriate measures put in place to protect the vegetables from exposure (gloves, a mask to prevent sneeze contamination, etc.) or, if this is not feasible, be disallowed from coming in contact with vegetables or any equipment that will contact the crop.

- Workers that have recently had enteric disease should, if allowed to work at all, be utilized in a non-vegetable handling capacity.

- Sending them home is, unfortunately, usually the best method of dealing with this.

\subsection{Disease transmission: cross contamination}

Probably the \#1 source of food-borne illness is unsanitary worker conditions.

Most of the diseases transmitted via fresh produce occur as part of the "fecal-oral pathway."

- This is the movement of human pathogens from an infected individuals waste to ingested material of a healthy person.
- Most commonly this occurs by the infected individual handling food without properly washing their hands.

- Employee hygiene, including hand washing and proper facility use, is an important step in breaking a pathogens pathway.

Open wounds can also contain pathogens. Use of a sealed covering (rubber or latex gloves; just a bandage is not sufficient) is the only way to contain them. The best method of reducing contamination from open sores or wounds is by removing affected employee(s) from situations where they may come in contact with produce, directly or indirectly.

3.4 Well-stocked hand-washing stations and restroom facilities

Employees can only maintain good hygiene if the proper facilities are available to them.

Restrooms in packinghouses must also have appropriate hand-washing facilities.

- Includes a place to remove any aprons, smocks and gloves and hang them outside of the restroom.

- Hand washing stations located outside of restrooms can aid supervisors in ensuring employee hygiene.

To be effective, all hand washing facilities should be well stocked with:

- A fresh water source (not re-circulated water)

- Soap

- A non-reusable hand drying system (disposable towels, air dryer, etc.)

- Possibly a sanitizing solution for use in conjunction with, but not to replace, proper hand washing

\subsection{Storage and Transport}

4.1 Cooling 
Human pathogens tend to grow slowly or not at all below $\sim 45^{\circ} \mathrm{F}\left(7^{\circ} \mathrm{C}\right)$. This is therefore the normal target for cooling systems. However, depending on the cultivar, growing region, maturity, treatments (such as waxing or temperature conditioning), etc., storage below $45^{\circ} \mathrm{F}$ may not be possible due to potential development of chilling injury. In such cases, these vegetables should be stored at their lowest safe temperature.

Cooler system coil maintenance and sanitation is also important (any pathogens growing in the air handlers of a forced-air cooler can potentially be blown into the stored commodity, possibly infesting an entire store).

\subsection{Storage room and vehicle cleanliness}

Be sure storage rooms and truck trailers are clean. If a trailer previously hauled raw meat, there is a great potential for contamination by several different human pathogens. Trailers should be cleaned appropriately if there are traces of odors or visible signs of foreign matter.

- If you cannot clean a suspect trailer, at least record its condition for later reference, if necessary.

\section{3 $\underline{\text { Reefer maintenance }}$}

Proper reefer maintenance should be done and recorded to avoid possible mishaps due to inappropriate shipping temperatures. Occasional use of a data logger to track temperature and cooler functionality/accuracy during transit is also desirable.

\subsection{Product loading and receiver unloading}

To maintain the cold chain, vegetables should never leave a refrigerated atmosphere, including loading/unloading docks. This is referred to as "the cold chain."

\section{5 "The Cold Chain"}

Once vegetables have been cooled to storage temperatures, they must remain at those temperatures to maintain an environment in which bacterial growth will be minimized. At any point in shipping or storage, if vegetables are removed from a cold environment and warmed to a level where microbial growth may begin, pathogenic cells may begin to multiply and would not be eliminated by being returned to a cold environment.

4.6 Impact of personnel, handling, loading and unloading on product safety

Use the same GAPs and sanitary guidelines as for field and packinghouse operations in terms of employee handling, loading, and unloading for produce safety. This is particularly important if handlers directly contact vegetables (culling, re-packing, etc.).

\subsection{Unpacking and Display}

\subsection{Product quality issues}

Even at the consumer level, the cold chain must be maintained. Removal of bruised and decaying vegetables while setting up and rotating displays reduces chances for human pathogen proliferation as well.

Use sanitation procedures in the back room and display area as outlined previously for earlier handling steps to avoid cross contamination between different foods or contamination by workers.

\subsection{Limit consumer handling}

Consumer packs may be preferable to bulk displays because they avoid possible contamination of vegetables by consumers while selecting produce.

\subsection{Documentation and Record-Keeping}

Keeping records is important to document adherence to GAPs and help identify potential problem areas.

- Keeping records helps alleviate legal responsibilities in a trace-back situation.

- Keep track of microbial test results, reefer and storage room temperature levels, any and all cleaning and maintenance activities, etc. 
- History has shown that, in a trace-back situation

following an outbreak, responsibility is often pinned on those with the least (or worst) kept records.

- Self-check lists are available from several commercial auditing companies. 